Research Square
Preprints are preliminary reports that have not undergone peer review.

They should not be considered conclusive, used to inform clinical practice, or referenced by the media as validated information.

\title{
Modeling and solving the parallel mixed-flow remanufacturing disassembly line balancing problem for multi-variety products*
}

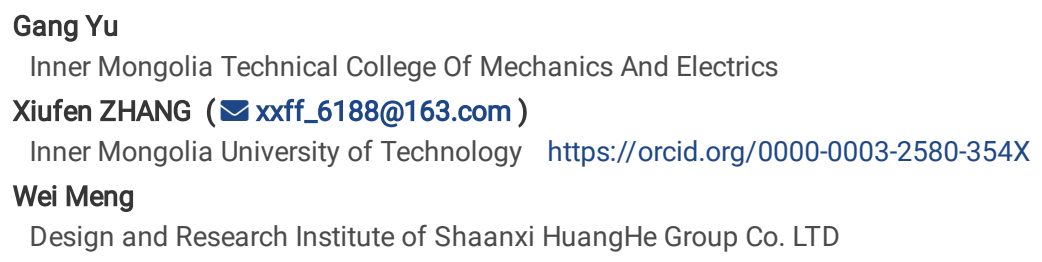

\section{Research Article}

Keywords: Multi-Variety, Parallel Mixed-Flow, Remanufacturing Disassembly Line Balancing, Multi-Objective Optimization, NSGA-III

Posted Date: January 19th, 2022

DOI: https://doi.org/10.21203/rs.3.rs-1244866/v1

License: (c) (i) This work is licensed under a Creative Commons Attribution 4.0 International License. Read Full License 


\section{Abstract}

The types and numbers of components in end-of-life (EOL) products are often uncertain during remanufacturing, leading to low disassembly efficiencies for traditional remanufacturing disassembly lines. To address this problem, a parallel mixed-flow workstation layout was designed, and a novel parallel mixed remanufacturing disassembly line balancing optimization method for multi-variety products was proposed. A mixed-flow product disassembly task hierarchical assignment matrix was constructed to perform disassembly task allocations for similar components. Furthermore, a parallel mixed-flow remanufacturing disassembly line balancing (PMRDLB) optimization model was developed with the optimization objectives of minimizing the number of workstations, the disassembly line balancing rate, and the remanufacturing value indexes of the components. Furthermore, the multi-objective non-dominated genetic optimization method (NSGA-III) was improved, in which a chromosome construction method, based on the parallel mixed-flow disassembly task allocation matrix, was proposed to conduct mapping between the chromosomes and the PMRDLB model. In addition, non-dominated solution sorting was performed based on a Pareto hierarchy, which increased the searching rate of the algorithm during optimization. Finally, a case study verified the effectiveness and feasibility of the proposed method.

\section{Introduction}

Remanufacturing is a profitable means of recovering end-of-life (EOL) products. Disassembly is the key step in obtaining the remanufacturing cores. The remanufacturing disassembly line balancing problem (RDLBP) focuses on obtaining an optimal disassembly line configuration scheme with reasonable task allocations, balanced workstation operations, a high disassembly efficiency, and a low cost, thereby reducing the remanufacturing costs [1-2].

Three classical disassembly line layouts exist: straight line, U-type, and parallel-type layouts. Therefore, the classical disassembly line balancing problem (DLBP) includes single-type linear bilateral disassembly line balancing [3], incomplete single-type linear disassembly line balancing [4], U-type disassembly line balancing [5-6], and single-type parallel disassembly line balancing [7-10].

Unfortunately, the types and numbers of components are often uncertain for EOL products during remanufacturing disassembly, which causes significant challenges for batch disassembly. The same types of products must be identified and rearranged for the existing disassembly lines, which is a complicated and low-efficiency process. Thus, much attention has been paid to parallel mixed-flow disassembly lines since they can significantly improve disassembly efficiency $[2,8]$.

The remainder of this article is organized into five additional sections. Section 2 presents a literature review. Section 3 describes the construction of a parallel mixed-flow remanufacturing disassembly line balancing (PMRDLB) optimization model. Optimization of the PMRDLB model, based on the multi-objective non-dominated genetic optimization method (NSGA-III), is described in Section 4. Section 5 presents a case study to validate the proposed model and method. Concluding remarks are provided in Section 6.

\section{Literature Review}

\subsection{Disassembly line balancing problem}

To increase the efficiency for large products, a two-sided layout was introduced, and a mathematical model for a stochastic two-sided partial DLBP with multiple objectives, multiple constraints, and uncertainty was constructed and resolved based on the multi-objective discrete flower pollination algorithm [3]. Li et al. [4] developed an incomplete single-type linear disassembly line balancing model and proposed the variable neighborhood particle swarm optimization algorithm. A profit-oriented U-shaped partial DLBP was proposed and solved using a discrete cuckoo search algorithm [5]. To improve the disassembly line production efficiency and reduce the production cost, the parallel disassembly line balancing problem was studied [7-8]. Zhu et al. [10] developed a mathematical model for a multi-objective locally parallel disassembly line balancing problem and solved the problem using the hybrid group neighborhood search algorithm. However, these methods did not work for a DLBP with multi-variety products, that is, a mixed disassembly of two different products in the workstation had not yet been achieved. Therefore, Agraeal and Tiwari [11] introduced the mixed product disassembly line concept and constructed a random mixed U-shaped disassembly line model. Model resolution was difficult using traditional methods. Later, Xia et al. [12] selected multiple products as the mixed products based on their structural similarities, developed a mixed disassembly line model under a random working environment, and solved the problem by adopting the adaptive simulated annealing genetic algorithm. Fang et al. [13] constructed a multi-robot hybrid disassembly line model and applied the evolutionary simulated annealing algorithm to obtain the optimal solution. Zeng et al. [14] constructed a multi-objective bucket-chain disassembly line model and proposed a multi-objective discrete flower pollination algorithm to solve the problem.

All of these researchers solved the mixed-flow disassembly line balancing problem by assuming multi-variety products as the mixed products. However, it becomes more difficult to construct a mixed product model as the products' types and complexities increase. Therefore, a hierarchical parallel workstation layout is introduced for the first time in this paper, and a PMRDLB model was constructed for multi-variety products.

\subsection{DLBP optimization Algorithm}

The DLBP can be solved primarily by mathematical programming, heuristic optimization, or meta-heuristic optimization. Mathematical programming produces high solution precision, but it is only suitable for solving small-scale disassembly line balancing tasks [15-18]. Heuristic methods can solve largescale disassembly line problems, but their solutions will be limited to local optima [19-20]. Meta-heuristic methods are the mainstream algorithms used to solve the DLBP; they include the multi-objective genetic algorithm (GA), the multi-objective genetic annealing algorithm, and the artificial fish swarm algorithm, among others [21-24]. These methods are often combined with multi-criteria decision technology when solving the problem [25]. Among them, the GA is robust and suitable for parallel computing and has been widely used for solving the DLBP [26-27]. Therefore, in this paper, which focuses on the layout 
characteristics of a multi-variety parallel mixed-flow remanufacturing disassembly line, an improved multi-objective non-dominated sorting genetic optimization method (Improved NSGA-III) is proposed to solve the PMRDLB problem.

\section{Parallel Mixed-flow Remanufacturing Disassembly Line Balancing (Pmrdlb) Model 3.1 Problem description}

There are different types of EOL products for remanufacturing with uncertain quantities. To achieve a reasonable allocation of disassembly tasks for different types of products, this paper proposes a parallel mixed-flow disassembly line layout, as shown in Fig. 1.

If there were two kinds of EOL products to be disassembled and the number of components was uncertain, two disassembly lines were required. Parallel stations were arranged on each disassembly line, such as stations S1 and S3 in Fig. 1. The two adjacent disassembly lines had mixed-flow disassembly stations, such as stations $\mathrm{S} 2$ and $\mathrm{Sm}$. All disassembly tasks were assigned to $N$ workstations according to the determined beat time, $C T$.

The parallel mixed-flow remanufacturing disassembly line balancing problem focused on attaining a reasonable allocation of disassembly tasks in the layout shown in Fig. 1 to minimize the number of disassembly stations, prioritize the disassembly of components with high remanufacturing values and hazardous material properties, and rationally utilize the factory space of the enterprise.

To simplify the problem, three assumptions were made:

(1) The disassembly time and remanufacturing value of each component were known, and all disassembly tasks were independent.

(2) A disassembly task could not be interrupted.

(3) The same disassembly task could not be assigned to multiple stations at the same time.

\subsection{Judgment conditions for the mixed-flow disassembly of multi-variety products}

Similarities and differences exist in the physical, material, and geometrical structures of various types of EOL products. Only products with certain similarities can be disassembled using a parallel mixed-flow disassembly line [12]. Therefore, it was necessary to determine the degree of product similarity.

It was assumed that the two disassembly task sets for the EOL products were

$\mathbf{P}_{1}=\left\{a_{1}^{1}, a_{2}^{1}, a_{3}^{1}, \cdots, a_{m 1}^{1}\right\}$ and $\mathbf{P}_{2}=\left\{a_{1}^{2}, a_{2}^{2}, a_{3}^{2}, \cdots, a_{m 2}^{2}\right\}$. The similar components set was

$\mathbf{S}=\bigcap\left\{a_{1}^{1}, a_{1}^{2}, a_{2}^{1}, a_{2}^{2}, a_{3}^{1}, a_{3}^{2} \cdots, a_{m 1}^{1}, a_{m 2}^{2}\right\}$, and the total components set was $P_{1} P_{2}=\bigcup\left\{a_{1}^{1}, a_{1}^{2}, a_{2}^{1}, a_{2}^{2}, a_{3}^{1}, a_{3}^{2} \cdots, a_{m 1}^{1}, a_{m 2}^{2}\right\}$. Thus, the similarity degree between the two products could be defined as follows:

$\lambda_{\text {pro }}=\frac{\cap\left\{a_{1}^{1}, a_{1}^{2}, a_{2}^{1}, a_{2}^{2}, a_{3}^{1}, a_{3}^{2} \cdots, a_{m 1}^{1}, a_{m 2}^{2}\right\}}{\cup\left\{a_{1}^{1}, a_{1}^{2}, a_{2}^{1}, a_{2}^{2}, a_{3}^{1}, a_{3}^{2} \cdots, a_{m 1}^{1}, a_{m 2}^{2}\right\}}=\frac{\mathbf{s}}{\mathbf{P}_{1} \mathbf{P}_{2}}, 0 \leq \lambda_{\text {pro }} \leq 1$. (1)

where $m 1$ and $m 2$ are the numbers of components in the two EOL products to be disassembled. The larger the similarity degree was, the greater was the similarity between the components in geometrical, physical, and material aspects, among others.

\subsection{Mathematical model for the PMRDLB problem}

A mathematical model for the PMRDLB problem was developed based on the parallel mixed-flow remanufacturing disassembly line layout shown in Fig. 1.

For clarification, the symbols utilized in the mathematical model are defined in Table 1. 
Table 1

Symbol definitions

\begin{tabular}{|c|c|}
\hline Symbol & Illustration \\
\hline mk & Number of the $k$ th EOL product's disassembly tasks \\
\hline $\mathrm{N}$ & Number of disassembly stations \\
\hline CT & Disassembly line beat time \\
\hline$t_{i l}$ & The disassembly time of the task $i$ on the Ith disassembly line \\
\hline $\mathrm{x}_{\mathrm{ilr}}$ & $\begin{array}{l}\text { Station task allocation coefficient, when the disassembly task } i \text { on the th } \\
\text { disassembly line is assigned to the rth station, it equals } 1 \text {, and otherwise, it equals } \\
0 .\end{array}$ \\
\hline $\mathrm{P}_{\mathrm{il}}$ & $\begin{array}{l}\text { Remanufacturing value of the components disassembled in the disassembly task } i \\
\text { of the Ith disassembly line, if the component has no remanufacturing value, it } \\
\text { equals } 0 \text {, and otherwise, it equals } 1 \text {. }\end{array}$ \\
\hline $\mathrm{S}_{\mathrm{r}}$ & Disassemble task set in station $r$ \\
\hline $\mathrm{L}_{\mathrm{il}}$ & $\begin{array}{l}\text { The position of component in the disassembly sequence in the ith disassembly } \\
\text { task of the Ith disassembly line }\end{array}$ \\
\hline$S_{i j}$ & Task $i$ takes precedence over task $j$ \\
\hline $\mathbf{p}^{k}$ & Disassembly priority mapping matrix of the EOL product $k$ \\
\hline $\mathbf{B}_{m k}^{k}$ & Disassembly task hazard mapping matrix of the EOL product $k$ \\
\hline $\mathrm{k}$ & Number of the disassembly lines \\
\hline $\mathbf{S}_{m k}^{k}$ & The comprehensive priority relation matrix of the EOL product $k$ \\
\hline $\mathrm{G}^{\mathrm{k}}$ & The comprehensive priority relation matrix of the EOL product $k$ \\
\hline G & The comprehensive disassembly tasks hierarchical matrix of EOL products \\
\hline
\end{tabular}

One clear difference between the PMRDLB problem and the traditional DLBP is the constraint conditions. All of the products in the parallel disassembly lines should not only meet the component disassembly priority relationship requirements but should also prioritize the disassembly of toxic and harmful components to reduce secondary pollution. This type of disassembly is more complex than single-product disassembly.

The disassembly priority relationship mapping matrix for the EOL product $k$ is given by

$$
\mathbf{P}_{m k}^{k}=\begin{gathered}
1 \\
2 \\
\vdots \\
m k
\end{gathered}\left(\begin{array}{cccc}
p_{11} & p_{12} & \cdots & p_{1 m k} \\
p_{21} & p_{22} & \cdots & p_{2 m k} \\
\vdots & \vdots & p_{i j} & \vdots \\
p_{m k 1} & p_{m k 2} & \cdots & p_{m k m k}
\end{array}\right\}_{m k \times m k}
$$

2

In Eq. (2), if task $i$ is performed before task $j$, then $p_{i j}=1$; otherwise, $p_{i j}=0$.

The component hazard mapping matrix for the EOL product $k$ is defined as follows:

$$
\mathbf{B}_{m k}^{k}=\begin{gathered}
1 \\
2 \\
\vdots \\
m k
\end{gathered}\left(\begin{array}{cccc}
b_{11} & b_{12} & \cdots & b_{1 m k} \\
b_{21} & b_{22} & \cdots & b_{2 m k} \\
\vdots & \vdots & b_{i j} & \vdots \\
b_{m k 1} & b_{m k 2} & \cdots & b_{m k m k}
\end{array}\right\}_{m k \times m k}
$$

3

In Eq. (3), if disassembly task $i$ is more hazardous than task $j$, then $b_{i j}=1$; otherwise, $b_{i j}=0$.

The disassembly priority relationship for the EOL product $k$ was deduced from $\mathbf{P}_{m k^{\prime}}^{k}, \mathbf{B}_{m k^{\prime}}^{k}$ and the comprehensive matrix $\mathbf{S}_{m k}^{k}$, asfollows: 


$$
\begin{gathered}
\mathbf{S}_{m k}^{k}=\mathbf{P}_{m k}^{k} \bigvee \mathbf{B}_{m k}^{k} \\
=\begin{array}{c}
1 \\
2 \\
M \\
m k
\end{array}\left(\begin{array}{cccc}
p_{11} \bigvee b_{11} & p_{12} \bigvee b_{12} & L & p_{1 m k} \bigvee b_{1 m k} \\
p_{21} \bigvee b_{21} & p_{22} \bigvee b_{22} & L & p_{2 m k} \bigvee b_{2 m k} \\
M & M & p_{i j} \bigvee b_{i j} & M \\
p_{m k 1} \bigvee b_{m k 1} & p_{m k 2} \bigvee b_{m k 2} & L & p_{m k m k} \bigvee b_{m k m k}
\end{array}\right)_{m k \times m k} \\
\end{gathered}
$$

4

In Eq. (4), $\mathbf{S}_{i j}^{k}$ indicates that if disassembly task $i$ has priority over task $j$, then $\mathbf{S}_{i j}=1$; otherwise, $\mathbf{S}_{i j}=0$.

According to Eq. (4), the feasibility conditions for disassembly task $j$ were defined as follows:

$$
\sum_{i=1}^{m k} \mathbf{S}_{i j}^{k}=0
$$

The products' disassembly tasks could be obtained from Eq. (5), and then, $\mathbf{S}_{m k}^{k}$ could be updated after disassembly. When $\mathbf{S}_{m k}^{k}=[0]_{m k \times m k}$ all the disassembly tasks were finished, and the disassembly task hierarchical matrix, $\mathbf{G}^{k}$, for the EOL product $k$ could be obtained.

The parallel mixed-flow disassembly task allocation matrix, $\mathbf{G}=\left\{\mathbf{G}^{1}, \mathbf{G}^{2}, \mathbf{G}^{3}, \ldots, \mathbf{G}^{k}\right\}$, shown in Fig. 2, could then be obtained from Eqs. (2)-(5).

Considering the uncertainty in the number of parts, during the construction of the disassembly sequence matrix for mixed-flow products, the largest number of parts among $k$ products should be taken as the matrix column standard, and the elements of the matrix with insufficient parts among the other products should be filled with 0 .

The mathematical model for the PMRDLB problem was formulated utilizing Eqs. (6)-(13).

$$
\min F=\left(f_{1}, f_{2}, f_{3}\right)
$$

6

$$
f_{1}=N
$$

7

$$
\begin{gathered}
f_{2}=\sqrt{\sum_{r=1}^{N}\left(C T-\sum_{l=1}^{k} \sum_{i=1}^{m k} t_{i l} \times x_{i l r}\right)^{2} / N,(8)} \\
f_{3}=\frac{\sum_{l=1}^{k} \sum_{i=1}^{m k}\left(L_{i l} \times P_{i l}\right)}{\sum_{l=1}^{k} \sum_{i=1}^{m k} L_{i l}}
\end{gathered}
$$

9

$$
\sum_{i=1}^{m k} \sum_{l=1}^{k} \sum_{r=1}^{N} x_{i l r}=1
$$

10

$$
\max _{r \in\{1,2, \cdots, N\}}\left\{\sum_{l=1}^{k} \sum_{i=1}^{m k}\left(x_{i l r} \times t_{i l}\right)\right\} \leq C T,
$$

11

$$
\frac{\sum_{l=1}^{k} \sum_{i=1}^{m k}\left(x_{i l r} \times t_{i l}\right)}{C T} \leq N \leq \sum_{l=1}^{k} \sum_{i=1}^{m k} x_{i l r}
$$


Eqs. (6)-(9) represent the optimization objects. In these equations, $f_{1}$ is the number of parallel mixed-flow disassembly line stations, $f_{2}$ is the station equalization rate, and $f_{3}$ is the average remanufacturing value index, which ensures disassembly of the higher value remanufacturing components first to avoid secondary-operation damage to the remanufacturing cores. Eq. (10) ensures that each disassembly line and disassembly task are assigned only to one station. Eq. (11) guarantees that the maximum total disassembly time in each disassembly station does not exceed the beat time, CT. Eq. (12) represents the workstation number range in the parallel disassembly line. Eq. (13) ensures that the priority relationship constraint is met for all of the disassembly tasks during an EOL product's disassembly.

\section{Pmrdlb Problem Solution Based On The Improved Nsga-iii}

Remanufacturing disassembly line balancing is a multi-objective optimization problem (MOP). The fast, non-dominated genetic algorithm NSGA-III with an elite strategy is characterized by fast operation and a high-precision solution. However, when it is used to solve the PMRDLB problem, its low sorting efficiency and unmatched hierarchical structure for disassembly tasks present significant challenges. Therefore, the NSGA-III algorithm was improved: the chromosome was coded based on the parallel mixed-flow disassembly task assignment matrix, and a non-dominant solution sorting method based on the Pareto rank was developed.

\subsection{Chromosome construction method based on the parallel mixed-flow disassembly task assignment matrix}

The multi-variety parallel mixed-flow remanufacturing disassembly line included many different kinds and quantities of EOL products. Therefore, a stratified two-segment chromosome coding method was proposed, as shown in Eq. (14).

$$
\text { code }=\left(\text { MixedS, FV) }=\left(\begin{array}{cccccc}
\mathrm{g}_{1}^{1} & \mathrm{~g}_{2}^{1} & \cdots & \mathrm{g}_{\mathrm{i}}^{1} & \cdots & \mathrm{g}_{\mathrm{m} 1}^{1} \\
\mathrm{~g}_{1}^{2} & \mathrm{~g}_{2}^{2} & \cdots & \mathrm{g}_{\mathrm{i}}^{2} & \cdots & \mathrm{g}_{\mathrm{m} 2}^{2} \\
\cdots & \cdots & \cdots & \cdots & \cdots & \cdots \\
\mathrm{g}_{1}^{\mathrm{k}} & \mathrm{g}_{2}^{\mathrm{k}} & \cdots & \mathrm{g}_{\mathrm{i}}^{\mathrm{k}} & \cdots & \mathrm{g}_{\mathrm{mk}}^{\mathrm{k}}
\end{array}\right),\left(\mathrm{f}_{1}, \mathrm{f}_{2}, \mathrm{f}_{3}\right)\right)
$$

14

In Eq. (14), the first segment, MixedS, represents the disassembly task sequences, and FVdenotes the multi-objective fitness function values. The number of workstations, $f_{1}$, the equalization rate, $f_{2}$, and the remanufacturing value index, $f_{3}$, could be decoded according to Eqs. (7)-(9).

To improve the convergence speed and solution precision of the algorithm, a chromosome construction method, which was based on the parallel mixed-flow disassembly task allocation matrix, was proposed to ensure that all chromosomes were feasible solutions under the constraints of the parallel mixed-flow remanufacturing disassembly line. The method contained four primary steps:

Step 1: According to the disassembly process scheme for EOL products, $k$ kinds of disassembly task priority matrices, $\mathbf{P}_{m}^{k}$, and hazard mapping matrices, $\mathbf{B}_{m}^{k}$ were constructed. The comprehensive priority matrix, $\mathbf{S}_{m}^{k}$, was deduced according to Eq. (4). The initial population matrix was defined as $\mathrm{Q}$, and the layered matrix, $\mathbf{G}^{k}$, of disassemblable parts of EOL products was defined as a zero matrix.

Step 2: The disassemblable parts were put into the disassembly task hierarchy matrix, $\mathbf{G}^{k}$, and the $\mathbf{S}_{m}^{k}$ matrix was simultaneously updated. It was determined whether $\mathbf{S}_{m}^{k}$ was a zero matrix. If so, $i$ was set to 1 and the method moved to Step 3; otherwise, Step 2 was repeated.

Step 3: The ith line in $\mathbf{G}^{k}$ was removed, pop gene fragments were randomly generated and stored in $\mathbf{Q}$, the ith line of $\mathbf{G}^{k}$ was set to 0 , and $i$ was incrementally increased.

Step 4: If $\mathbf{G}^{k}$ was determined to be a zero matrix, $\mathbf{Q}$ was output; if not, the method returned to Step 3.

A flowchart for the chromosome construction method is shown in Fig. 3.

\subsection{Chromosome evolutionary rules}

The initial population could be determined according to the chromosome acquisition method presented in Fig. 3, and the offspring population would be generated by chromosome cross and mutation operations. Furthermore, the structural reference points were established based on the Pareto rank.

\subsubsection{Cross and mutation operations}

Two paternal chromosomes, 1 and 2, were randomly selected from the initial population, and two cross sites, 1 and 2, on the paternal chromosomes were randomly determined. The gene fragments between the two cross sites were called fragments 1 and 2, and the gene containing fragment 2 on paternal 
chromosome 1 was deleted. The gene containing fragment 1 on paternal chromosome 2 was also deleted, and fragment 2 was inserted into paternal chromosome 1 according to the cross positions 1 and 2 to form a new chromosome 1 . Fragment 1 was inserted into paternal chromosome 2 according to the cross positions 1 and 2 to form a new chromosome 2 . Two mutation sites, 1 and 2, were determined randomly, and genes were exchanged at these sites on the new chromosomes to form offspring chromosomes, 1 and 2. The schematic chromosome crossover and variation diagram is shown in Fig. 4(a). The selected chromosome genes mutated to produce new chromosomes, as shown in Fig. 4(b).

\subsubsection{Non-dominated ranking}

During the comparison process, if $R 1$ and $R 2$ fulfilled $f_{i}(R 1) \leq f_{i}(R 2)(\forall i \in(1,2,3))$, then $R 1$ dominated $R 2$. If $R 1$ was not dominated by other vectors, then $R 1$ was the Pareto solution.

The dominant relationship was determined by a Pareto comparison of the objective function values of $R 1$ and $R 2$. When $R 1$ dominated $R 2$, the Pareto level of $R 1$ was 1 and was denoted as Pareto 1. Similarly, the chromosomes' Pareto levels could also be obtained.

The $(s+1)$ th generation was a combination of the parent population and the progeny population and was sorted according to the chromosomes' Pareto ranks.

\subsection{Generation of the structured reference points}

The NSGA-III ensures solution diversity by using a predefined set of reference points, which can be defined in a structured manner [19]. Reference points were uniformly distributed points in the PMRDLB model's solution space, which was in an $(M-1)$ dimensional hyperplane, where $M$ is the dimension of the target space, namely, the number of optimized targets. If each target was divided into $H$ parts, there were four primary reference point generation steps:

Step 1: The number of reference points, $H$, was determined using the following equation:

$H=C_{M+p-1}^{p}(15)$

where the pth coordinate axis was divided into several parts.

Step 2: The extremum point of the objective function was determined. The target value was very large, and the target value of the individual corresponded to the small points on other target values. The minimum value of the three objective functions in this study was $\bar{Z}=\left(z_{1}^{\mathrm{min}}, Z_{2}^{\mathrm{min}}, Z_{3}^{\mathrm{min}}\right)$; so, the extreme point was solved according to Eq. (16).

$$
\dot{f_{i}}(\mathrm{x})=f_{i}(\mathrm{x})-z_{i}^{\min }
$$

16

Step 3: The distances between the target point and the reference points on extract chromosomes were calculated, and the selected chromosomes were added to the next generation population.

Step 4: Steps 2 and 3 were repeated until the population size was consistent.

\subsection{PMRDLB model optimization process}

Optimizing the PMRDLB model was performed to achieve a reasonable allocation of disassembly tasks at the stations. The optimization process included five primary steps: data preparation, initial population acquisition, non-dominated ranking based on the Pareto level, structured reference point generation, and optimal solution output.

Step 1: In the data preparation stage, the disassembly process plan for EOL products was analyzed to obtain the comprehensive priority relationship matrix and define and initialize the parameters, such as the population size (pop), the beat time (CT), and the number of iterations (Gen).

Step 2: The disassembly task allocation matrix was obtained, the objective function value was calculated, the chromosomes were generated, and the initial population was established.

Step 3: The offspring population was generated by cross and mutation operations. The parent and child populations were combined, and the chromosomes' Pareto ranks were determined.

Step 4: Next-generation chromosomes were extracted based on the structured reference points.

Step 5: The optimal non-dominated solution set was obtained.

The solution process for the PMRDLB problem, which was based on the improved NSGA-III algorithm, is shown in Fig. 5.

\section{Case Study}

To verify the feasibility and effectiveness of the proposed method, a 34-component engine [32] and a 37-component Passat B5 engine [33] were selected for a case study. The remanufacturing values were generated by random numbers ranging from 0 to 100 , and the component information is presented in Table 2 . 
Table 2

Component information for the two engine types

\begin{tabular}{|c|c|c|c|c|c|c|c|c|c|}
\hline $\begin{array}{l}34 \\
\text { Task } \\
\text { No. }\end{array}$ & Part name & $\begin{array}{l}\text { Takedown } \\
\text { time(s) }\end{array}$ & $\begin{array}{l}\text { Remanufacturing } \\
\text { value }\left({ }^{\ddagger}\right)\end{array}$ & Harmfulness & $\begin{array}{l}37 \\
\text { Task } \\
\text { No }\end{array}$ & Part name & $\begin{array}{l}\text { Takedown } \\
\text { time(s) }\end{array}$ & $\begin{array}{l}\text { Remanufacturing } \\
\text { value }\left({ }^{\ddagger}\right)\end{array}$ & Harmfulness \\
\hline 1 & $\begin{array}{l}\text { Alternator support } \\
\text { bracket }\end{array}$ & 38 & 5 & no & 1 & Igniter & 164 & 82 & yes \\
\hline 2 & Alternator & 23 & 65 & yes & 2 & Valve cover & 96 & 91 & no \\
\hline 3 & Drive belt & 30 & 0 & no & 3 & Camshaft & 326 & 12 & no \\
\hline 4 & Water pump pulley & 56 & 15 & no & 4 & $\begin{array}{l}\text { Valve } \\
\text { assembly }\end{array}$ & 251 & 92 & no \\
\hline 5 & Special washers & 161 & 35 & no & 5 & Timing belt & 0 & 63 & no \\
\hline 6 & Crankshaft Pulley & 10 & 40 & no & 6 & $\begin{array}{l}\text { Camshaft } \\
\text { drive wheel }\end{array}$ & 49 & 9 & no \\
\hline 7 & Pulley & 12 & 45 & no & 7 & $\begin{array}{l}\text { Timing belt } \\
\text { tensioning } \\
\text { wheel }\end{array}$ & 56 & 28 & no \\
\hline 8 & Oil level indicator & 12 & 65 & no & 8 & $\begin{array}{l}\text { Timing belt } \\
\text { toothed belt } \\
\text { wheel }\end{array}$ & 40 & 55 & no \\
\hline 9 & $\begin{array}{l}\text { Synchronous band } \\
\text { cover }\end{array}$ & 70 & 8 & no & 9 & $\begin{array}{l}\text { Crankshaft } \\
\text { Gear }\end{array}$ & 156 & 96 & no \\
\hline 10 & $\begin{array}{l}\text { Synchronous belt } \\
\text { lower cover }\end{array}$ & 140 & 8 & no & 10 & $\begin{array}{l}\text { Intake } \\
\text { manifold }\end{array}$ & 163 & 97 & yes \\
\hline 11 & Timing belt & 45 & 0 & no & 11 & $\begin{array}{l}\text { Exhaust } \\
\text { manifold }\end{array}$ & 145 & 15 & no \\
\hline 12 & Belt tension spring & 34 & 60 & no & 12 & Air cleaner & 93 & 98 & yes \\
\hline 13 & Tensioner & 34 & 70 & no & 13 & Intake pipe & 54 & 96 & no \\
\hline 14 & $\begin{array}{l}\text { Crankshaft } \\
\text { sprocket flange }\end{array}$ & 70 & 30 & no & 14 & Turbocharger & 56 & 49 & no \\
\hline 15 & $\begin{array}{l}\text { Crankshaft } \\
\text { sprocket }\end{array}$ & 10 & 45 & no & 15 & $\begin{array}{l}\text { Supercharger } \\
\text { flywheel }\end{array}$ & 86 & 80 & no \\
\hline 16 & Water pump & 56 & 95 & yes & 16 & $\begin{array}{l}\text { Supercharger } \\
\text { belt }\end{array}$ & 0 & 14 & no \\
\hline 17 & $\begin{array}{l}\text { Rocker cover and } \\
\text { gasket }\end{array}$ & 11 & 50 & no & 17 & $\begin{array}{l}\text { Supercharger } \\
\text { belt } \\
\text { tensioning } \\
\text { wheel }\end{array}$ & 72 & 42 & no \\
\hline 18 & Intake pipe & 180 & 40 & no & 18 & $\begin{array}{l}\text { Supercharger } \\
\text { pump wheel }\end{array}$ & 94 & 92 & no \\
\hline 19 & Exhaust pipe & 144 & 40 & no & 19 & $\begin{array}{l}\text { Engine } \\
\text { support } \\
\text { frame }\end{array}$ & 76 & 80 & no \\
\hline 20 & $\begin{array}{l}\text { Cylinder } \square \\
\text { Distributor } \square \\
\text { Camshaft } \square \text { Valve }\end{array}$ & 730 & 95 & no & 20 & $\begin{array}{l}\text { Cylinder } \\
\text { block }\end{array}$ & 240 & 96 & no \\
\hline 21 & Oil filter & 60 & 65 & no & 21 & $\begin{array}{l}\text { Connecting } \\
\text { Rod }\end{array}$ & 162 & 66 & no \\
\hline 22 & Oil receiver & 126 & 40 & no & 22 & Large tile & 76 & 3 & no \\
\hline 23 & Oil screen & 38 & 40 & no & 23 & Small tile & 74 & 85 & no \\
\hline 24 & Oil cap & 10 & 25 & no & 24 & $\begin{array}{l}\text { connecting } \\
\text { rod cover }\end{array}$ & 153 & 94 & no \\
\hline 25 & Front case & 84 & 15 & no & 25 & $\begin{array}{l}\text { Crankshaft } \\
\text { main bearing } \\
\text { cap }\end{array}$ & 72 & 68 & no \\
\hline 26 & Oil pump & 54 & 95 & no & 26 & Crankshaft & 312 & 76 & no \\
\hline 27 & $\begin{array}{l}\text { Pistons, connecting } \\
\text { rod }\end{array}$ & 24 & 30 & no & 27 & Oil pump & 50 & 75 & no \\
\hline
\end{tabular}




\begin{tabular}{|c|c|c|c|c|c|c|c|c|c|}
\hline $\begin{array}{l}34 \\
\text { Task } \\
\text { No. }\end{array}$ & Part name & $\begin{array}{l}\text { Takedown } \\
\text { time(s) }\end{array}$ & $\begin{array}{l}\text { Remanufacturing } \\
\text { value }\left({ }^{\ddagger}\right)\end{array}$ & Harmfulness & $\begin{array}{l}37 \\
\text { Task } \\
\text { No }\end{array}$ & Part name & $\begin{array}{l}\text { Takedown } \\
\text { time(s) }\end{array}$ & $\begin{array}{l}\text { Remanufacturing } \\
\text { value }\left({ }^{\ddagger}\right)\end{array}$ & Harmfulness \\
\hline 28 & $\begin{array}{l}\text { The connecting rod } \\
\text { cup }\end{array}$ & 24 & 30 & no & 28 & $\begin{array}{l}\text { Oil pump } \\
\text { chain }\end{array}$ & 175 & 39 & no \\
\hline 29 & Flywheel & 675 & 45 & no & 29 & $\begin{array}{l}\text { Intake } \\
\text { camshaft } \\
\text { lock block }\end{array}$ & 115 & 66 & no \\
\hline 30 & Thick steel plate & 44 & 50 & no & 30 & $\begin{array}{l}\text { Vent } \\
\text { camshaft } \\
\text { lock block }\end{array}$ & 115 & 17 & no \\
\hline 31 & Engine bell housing & 36 & 65 & no & 31 & Oil Pan & 123 & 71 & no \\
\hline 32 & Oil seal cover & 63 & 30 & no & 32 & $\begin{array}{l}\text { Transmission } \\
\text { assembly }\end{array}$ & 183 & 3 & no \\
\hline 33 & Rear oil seal & 30 & 25 & no & 33 & $\begin{array}{l}\text { Clutch } \\
\text { flywheel }\end{array}$ & 72 & 27 & no \\
\hline 34 & Crankshaft & 530 & 55 & no & 34 & $\begin{array}{l}\text { Clutch } \\
\text { pressure } \\
\text { plate }\end{array}$ & 65 & 4 & no \\
\hline 1 & 1 & 1 & 1 & 1 & 35 & Clutch cover & 82 & 9 & no \\
\hline 1 & 1 & 1 & 1 & 1 & 36 & Air Cylinder & 265 & 83 & no \\
\hline 1 & 1 & 1 & 1 & 1 & 37 & Clutch Disc & 12 & 70 & no \\
\hline
\end{tabular}

\subsection{Calculations of structural similarity between the two engines}

The 34-component engine and the 37-component Passat B5 engine were two different kinds of engines with different uses. A similarity analysis was conducted on the two engines using expert judgment, and the results are presented in Table 3.

Table 3

Results of a similarity analysis of the two engines

\begin{tabular}{|c|c|c|c|}
\hline Criteria & Task 34 Engine parts & Task 37 Passat B5 engine parts & $\begin{array}{l}\text { Similar } \\
\text { structure }\end{array}$ \\
\hline \multirow[t]{6}{*}{$\begin{array}{l}\text { Structural } \\
\text { similarity }\end{array}$} & $\begin{array}{l}\text { Drive belt, Water pump pulley, Crankshaft pulley, Belt pulley, } \\
\text { Synchronous belt cover, Synchronous belt cover, Synchronous belt, } \\
\text { Belt tension spring, Belt tensioner }\end{array}$ & $\begin{array}{l}\text { Timing belt, Timing belt tensioning wheel, Timing belt } \\
\text { toothed belt wheel, Supercharger belt, Supercharger } \\
\text { belt tensioning wheel }\end{array}$ & $\begin{array}{l}\text { Belt } \\
\text { structure }\end{array}$ \\
\hline & Piston, Rod, Rod cup & $\begin{array}{l}\text { Connecting rod, Large tile, Small tile, Connecting rod } \\
\text { cover }\end{array}$ & $\begin{array}{l}\text { Connecting } \\
\text { rod } \\
\text { construction }\end{array}$ \\
\hline & Crankshaft, Camshaft & $\begin{array}{l}\text { Crankshaft main bearing cover, Crankshaft,Intake } \\
\text { Camshaft lock block, Outlet camshaft lock block, } \\
\text { Camshaft }\end{array}$ & $\begin{array}{l}\text { Shafting } \\
\text { structure }\end{array}$ \\
\hline & Air cylinder, Intake pipe, Exhaust pipe & $\begin{array}{l}\text { Cylinder, Cylinder block, Intake pipe, Outlet } \\
\text { manifold,Intake manifold, Valve assembly,Valve cover }\end{array}$ & $\begin{array}{l}\text { Cylinder } \\
\text { construction }\end{array}$ \\
\hline & Crankshaft sprocket flange, Crankshaft sprocket & Oil pump chain & $\begin{array}{l}\text { Sprocket } \\
\text { structure }\end{array}$ \\
\hline & $\begin{array}{l}\text { Back oil seal, Sealing oil cap, Oil pump, Oil cap, Oil filter net, Oil pan, } \\
\text { Oil filter, Oil level indicator }\end{array}$ & Oil pump, oil sump & $\begin{array}{l}\text { Oil pump } \\
\text { structure }\end{array}$ \\
\hline
\end{tabular}

According to Eq. (1), the product similarity, $\lambda_{\text {pro }}=\frac{\bigcap\left\{a_{1}^{1}, a_{1}^{2}, a_{2}^{1}, a_{2}^{2}, a_{3}^{1}, a_{3}^{2} \cdots, a_{m 1}^{1}, a_{m 2}^{2}\right\}}{\bigcup\left\{a_{1}^{1}, a_{1}^{2}, a_{2}^{1}, a_{2}^{2}, a_{3}^{1}, a_{3}^{2} \cdots, a_{m 1}^{1}, a_{m 2}^{2}\right\}}=\frac{\mathbf{s}}{\mathbf{P}_{1} \mathbf{P}_{2}}=\frac{51}{71}=0.71$, was obtained, which satisfied $\lambda$ pro $\geq 0.7$.

Therefore, the mixed-flow disassembly line operation could be conducted.

\subsection{Problem-solving}

The computer used in the case study was an Intel(R) Core I5-6200U CPU with $2.30 \mathrm{GHz}$ and $12 \mathrm{~GB}$ RAM. The PMRDLB prototype system was developed using a professional edition of MATLAB R2016a in Windows 10.

After building the disassembly task allocation matrix according to Eqs. (2) - (6), the number of iterations and the population size were set to Gen $=200$ and pop $=50$, respectively. The disassembly task time, $730 \mathrm{~s}$, was the total task time of the maximum disassembly workstation for the 34 -component engine. Therefore, the beat time was $C T \geq 730 \mathrm{~s}$, and five optimal disassembly line configuration schemes were obtained by many experiments, as shown in Table 4 . 


\begin{tabular}{|c|c|c|c|c|c|c|c|c|c|c|}
\hline Plan & Plan 1 & & Plan 2 & & Plan 3 & & Plan 4 & & Plan 5 & \\
\hline Engine name & Task 34 & Task 37 & Task 34 & Task 37 & Task 34 & Task 37 & Task 34 & Task 37 & Task 34 & Task 37 \\
\hline \multirow[t]{37}{*}{ Disassembly Task Number } & 21 & 1 & 22 & 1 & 18 & 13 & 3 & 7 & 3 & 1 \\
\hline & 18 & 7 & 21 & 7 & 21 & 35 & 8 & 19 & 18 & 7 \\
\hline & 8 & 13 & 18 & 19 & 22 & 19 & 9 & 17 & 19 & 17 \\
\hline & 3 & 17 & 3 & 35 & 19 & 7 & 18 & 35 & 8 & 13 \\
\hline & 9 & 19 & 8 & 13 & 9 & 1 & 21 & 13 & 22 & 35 \\
\hline & 19 & 35 & 9 & 17 & 8 & 17 & 22 & 1 & 9 & 19 \\
\hline & 22 & 5 & 19 & 16 & 3 & 5 & 19 & 2 & 21 & 32 \\
\hline & 4 & 12 & 1 & 5 & 4 & 12 & 1 & 12 & 4 & 16 \\
\hline & 1 & 32 & 17 & 12 & 5 & 32 & 5 & 16 & 23 & 5 \\
\hline & 5 & 16 & 4 & 2 & 1 & 2 & 4 & 32 & 1 & 2 \\
\hline & 23 & 2 & 5 & 32 & 17 & 16 & 23 & 5 & 5 & 12 \\
\hline & 17 & 8 & 23 & 10 & 23 & 8 & 17 & 33 & 17 & 30 \\
\hline & 2 & 10 & 2 & 33 & 16 & 30 & 2 & 30 & 16 & 33 \\
\hline & 16 & 30 & 16 & 8 & 2 & 10 & 16 & 29 & 2 & 10 \\
\hline & 6 & 11 & 6 & 30 & 6 & 29 & 6 & 11 & 6 & 11 \\
\hline & 7 & 15 & 7 & 11 & 7 & 15 & 7 & 8 & 7 & 6 \\
\hline & 10 & 29 & 10 & 6 & 10 & 6 & 10 & 10 & 10 & 8 \\
\hline & 12 & 6 & 12 & 9 & 12 & 9 & 12 & 15 & 12 & 9 \\
\hline & 11 & 9 & 13 & 29 & 13 & 33 & 13 & 6 & 11 & 29 \\
\hline & 13 & 33 & 11 & 15 & 11 & 11 & 11 & 9 & 13 & 15 \\
\hline & 14 & 18 & 14 & 18 & 14 & 18 & 14 & 18 & 15 & 18 \\
\hline & 15 & 14 & 15 & 14 & 15 & 14 & 15 & 14 & 14 & 14 \\
\hline & 25 & 34 & 25 & 34 & 24 & 3 & 25 & 3 & 20 & 34 \\
\hline & 24 & 3 & 20 & 3 & 20 & 34 & 24 & 34 & 25 & 3 \\
\hline & 20 & 4 & 24 & 37 & 25 & 4 & 20 & 4 & 24 & 4 \\
\hline & 26 & 37 & 27 & 4 & 26 & 37 & 28 & 37 & 26 & 37 \\
\hline & 27 & 31 & 26 & 31 & 27 & 31 & 26 & 31 & 27 & 31 \\
\hline & 28 & 28 & 28 & 28 & 28 & 28 & 27 & 28 & 28 & 25 \\
\hline & 29 & 25 & 29 & 24 & 29 & 24 & 29 & 25 & 29 & 28 \\
\hline & 34 & 24 & 30 & 25 & 34 & 25 & 34 & 24 & 30 & 24 \\
\hline & 30 & 27 & 34 & 22 & 30 & 27 & 30 & 27 & 34 & 23 \\
\hline & 31 & 23 & 31 & 23 & 31 & 22 & 31 & 23 & 31 & 22 \\
\hline & 32 & 22 & 32 & 27 & 32 & 23 & 32 & 22 & 32 & 27 \\
\hline & 33 & 21 & 33 & 21 & 33 & 21 & 33 & 21 & 33 & 21 \\
\hline & I & 36 & I & 36 & I & 36 & I & 36 & I & 36 \\
\hline & I & 26 & I & 26 & I & 26 & I & 26 & I & 26 \\
\hline & I & 20 & I & 20 & I & 20 & I & 20 & I & 20 \\
\hline Number of workstations $f_{1}$ & \multicolumn{2}{|l|}{$f_{1}=9$} & \multicolumn{2}{|l|}{$f_{1}=10$} & \multicolumn{2}{|l|}{$f_{1}=10$} & \multicolumn{2}{|l|}{$f_{1}=11$} & \multicolumn{2}{|l|}{$f_{1}=9$} \\
\hline Equilibrium rate $f_{2}$ & \multicolumn{2}{|l|}{$f_{2}=33.50$} & \multicolumn{2}{|l|}{$f_{2}=52.30$} & \multicolumn{2}{|l|}{$f_{2}=55.40$} & \multicolumn{2}{|l|}{$f_{2}=65.30$} & \multicolumn{2}{|l|}{$f_{2}=45.8$} \\
\hline Remanufacturing value index $f_{3}$ & \multicolumn{2}{|l|}{$f_{3}=98.59$} & \multicolumn{2}{|l|}{$f_{3}=99.52$} & \multicolumn{2}{|l|}{$f_{3}=97.56$} & \multicolumn{2}{|l|}{$f_{3}=94.32$} & \multicolumn{2}{|l|}{$f_{3}=97.35$} \\
\hline
\end{tabular}


Taking plan 1 as an example, the disassembly task assignment results are shown in Fig. 6.

To verify the effectiveness of the model and method proposed in this paper, the objective function values $f_{1}, f_{2}$, and $f_{3}$ of the mixed-flow disassembly line for task 1 under different layout forms were compared, and the results are shown in Table 5.

Table 5

Comparison of solution results for remanufacturing disassembly lines with different layouts

\begin{tabular}{|llll|}
\hline Layout forms & Number of workstations $\boldsymbol{f}_{\mathbf{1}}$ & Workstation equalization rate & Average remanufacturing value index $\boldsymbol{f}_{3}$ \\
\hline Parallel mixed-flow & 9 & $\boldsymbol{f}_{2}$ & \\
\hline Straight line mixed-flow & 11 & 33.50 & 98.59 \\
\hline U type mixed-flow & 10 & 101.66 & 1959.43 \\
\hline
\end{tabular}

Table 5 shows that, compared with other layout forms, the parallel mixed-flow remanufacturing disassembly line improved the disassembly efficiency and had obvious advantages for solving the multi-variety EOL product disassembly problem. The disassembly line model for parallel mixed-flow remanufacturing proposed in this paper overcame the above shortcomings and solved the problem when there were many kinds of recovered waste products and the number of parts was uncertain. Experimental results showed that the method was feasible and effective.

\section{Conclusions}

There are many types of EOL products in remanufacturing disassembly lines, and the number of components is often uncertain. To solve this problem, a PMRDLB optimization model was proposed in this paper, and the NSGA-III algorithm was improved. Two engine cases were studied to verify the validity of the proposed model and method. The method had three primary highlights:

(1) In view of the uncertain characteristics of multi-variety products in remanufacturing disassembly lines, a parallel mixed-flow remanufacturing disassembly line layout was designed. It not only made reasonable use of space but also improved the efficiency of parallel mixed-flow disassembly for multi-variety products.

(2) A construction method for the mixed-flow product disassembly task allocation matrix was proposed, which overcame the difficulties of model construction and low computational efficiency caused by the traditional mixed disassembly line in which multiple products were regarded as a single imaginary mixed product.

(3) The NSGA-III algorithm was improved to solve the PMRDLB problem. A stratified two-segment chromosome coding method was adopted to ensure that all solutions were feasible. This method also improved the optimization efficiency.

\section{Declarations}

Acknowledgements We thank LetPub (www.letpub.com) for its linguistic assistance during the preparation of this manuscript.

Author contribution Conceptualization, G. Yu, X.F. Zhang, and W. Meng; methodology, G. Yu and W.Meng; Validation, G. Yu and W.Meng; formal analysis, G.Yu; investigation,G. Yu,X.F. Zhang and W.Meng; resources, W.Meng and X.F. Zhang; data curation, W.Meng and G. Yu; writing-original draft reparation, G.Yu and W.Meng; writing-review and editing, G.Yu; visualization, G.Yu and W.Meng;supervision,X.F.Zhang;project adimistration, X.F.Zhang; funding acquisition, X.F.Zhang. All authors have read and agreed to the published version of the manuscript.

Funding This article is supported by the National Natural Science Foundation of China (No. 51965049)and Key Technology Research Plan of Inner Mongolia Autonomous Region(2021GG0261).

Ethics approval All analyses were based on previous published studies; thus, no ethical approval and patient consent are required.

Consent to participate Not applicable.

Consent for publication A statement under the "Consent to publish" heading confirming that you have obtained consent to publish from the participant (or legal parent or guardian for children) to report individual patient data. Note that this is required where an article reports an individual participant's data in any form (including images, videos, and voice recordings).

Competing interests The authors declare no competing interests.

\section{References}

1. KAZANCOGLU Y, OZTURKOGLU Y (2018) Integrated framework of disassembly line balancing with Green and business objectives using a mixed MCDM[J]. J Clean Prod 191:179-191

2. Deniz N, Ozcelik F (2019) An extended review on disassembly line balancing with bibliometric \& social network and future study realization analysis[J]. J Clean Prod 225:697-715 
3. Wang K, Li X, Gao L (2019a) A multi-objective discrete flower pollination algorithm for stochastic two-sided partial disassembly line balancing problem[J]. Comput Ind Eng 130:634-649

4. Liuke LI, Zeqiang ZHANG, Lixia ZHU et al (2018) Modeling and Optimizing for Multi-objective Partial Disassembly Line Balancing Problem. Journal of Mechanical Engineering[J] 54(3):1090-1097. (in Chinese)

5. Li Z, Janardhanan MN .Modelling and solving profit-oriented U-shaped partial disassembly line balancing problem[J].Expert systems with applications,2021,183,115431. https://doi.org/10.1016/j.eswa.2021.115431

6. LI Z, KUCUKKOC I, ZHANG Z (2019) Iterated local search method and mathematical model for sequence-dependent U-shaped disassembly line balancing problem[J]. Comput-ers \& Industrial Engineering 137:106056

7. AYDEMIR K A TURKBEYO (2013) Multi-objective optimiza-tion of stochastic disassembly line balancing with station paralleling[J]. Comput Ind Eng 65(3):413-425

8. HEZRE S (2015) A Network-based Shortest Route Model for Parallel Disassembly Line Balancing Problem[J]. Int J Prod Res 53(6):1849-1865

9. Zeqiang ZHANG, Ning CAl, Liuke LI et al (2018) Review of Modeling Theory and Solution Method for Disassembly Line Balancing Problems for Remanufacturing[J], vol 29. CHINA MECHANICAL ENGINEERING, pp 2636-2645. 21(in Chinese)

10. Zhu L, Zhang Z, Guan C (2020) Multi-objective partial parallel disassembly line balancing problem using hybrid group neighbourhood search algorithm[J]. J Manuf Syst 56:252-269

11. AGRAWAL S, TIWARI M K. (2008) A collaborative ant colony algorithm to stochastic mixed-model U-shaped disassembly line balancing and sequencing problem[J]. Int J Prod Res 46(6):1405-1429

12. XIA X, LIU W, ZHANG Z et al (2019) A Balancing Method of Mixed-model Disassembly Line in Random Working Envi-ronment[J]. Sustainability 11(8):2304

13. FANG Y, MING H, LI M et al (2019) Multi-objective evolu-tionary simulated annealing optimization for mixed-model multi-robotic disassembly line balancing with interval pro-cessing time[J]. International Journal of Production Re-search 1:1-17

14. Yanqing ZENG, Zeqiang ZHANG, Ying ZHANG et al (2020) Pareto flower pollination algorithm for multi-objective bucket brigade mixed-model disassembly line balancing problem[J]. Comput Integr Manuf Syst 26(03):760-774. (in Chinese)

15. Qingxin XIAO, Xiuping GUO, Xinjun GU (2019) The Stochastic Mixed-Model U-Shaped Disassembly Line Balancing and Sequencing Optimization Problem with Multiple Con-straints[J]. Industrial Engineering and Management 24(05):87-96. (in Chinese)

16. PAKSOY T, GÜNGÖR A (2013) Mixed model disassembly line balancing problem with fuzzy goals[J]. Int J Prod Res 51(20):6082-6096

17. AGRAWAL S, TIWARI M K. (2008) A collaborative ant colony algorithm to stochastic mixed-model U-shaped disassem-bly line balancing and sequencing problem[J]. Interna-tional Journal of Production Research 46(6):1405-1429

18. ALTEKIN F T KANDILLERL, OZDEMIREL N E (2008) Profit-oriented disassembly-line balancing[J]. Int J Prod Res 46(10):2675-2693

19. FANG Y, LIU Q, LI M et al (2019) Evolutionary many-objective optimization for mixed-model disassembly line balancing with multi-robotic workstations[J]. Eur J Oper Res 276(1):160-174

20. METE S, ÇIL Z A, AĞPAK K et al (2016) A solution approach based on beam search algorithm for disassembly line balancing problem[J]. J Manuf Syst 41:188-200

21. ÇIL Z A METES, CELIK E et al (2019) Supply-driven re-balancing of disassembly lines: A novel mathematical model approach[J]. J Clean Prod 213:11571164

22. JIN Y D, FENG J B, ZHANG W J. UAV Task Allocation for Hierarchical Multi-objective Optimization in Complex Conditions Using Modified NSGA-III with Segmented Encoding[J].Journal of Shanghai Jiaotong University (Science), 2021(prepublish).

23. REN Y, ZHANG C, ZHAO F et al (2018) Disassembly line balancing problem using interdependent weights-based multi-criteria decision making and 2Optimal algorithm[J]. J Clean Prod 174:1475-1486

24. WANG K, Li X, Gao L LI. A genetic simulated annealing algorithm for parallel partial disassembly line balancing problem[J]. Applied Soft Computing Journal,2021,107.

25. WANG K, LI X (2019b) Modeling and optimization of multi-objective partial disassembly line balancing problem considering hazard and profit[J]. Journal of Cleaner Pro-duction 211:115-133

26. ZHU L, ZHANG Z, WANG Y (2018) A Pareto firefly algorithm for multi-objective disassembly line balancing problems with hazard evaluation[J]. International Journal of Pro-duction Research 56(24):7354-7374

27. PISTOLESI F, LAZZERINI B, MURA MD et al (2018) EMOGA: A Hybrid Genetic Algorithm With Extremal Optimization Core for Multi-objective Disassembly Line Balancing[J]. IEEE Trans Industr Inf 14(3):1089-1098

28. ZHANG Z, WANG K, ZHU L et al (2017) A Pareto improved artificial fish swarm algorithm for solving a mul-ti-objective fuzzy disassembly line balancing problem[J]. Expert Syst Appl 86:165-176

29. WANG K, LI X (2019) GAO L, et al. Partial disassembly line balancing for energy consumption and profit under un-certainty[J], vol 59. Robotics and Computer-Integrated Manu-facturing, pp 235-251

30. MCGOVERN S M, GUPTA SM (2007) A balancing method and genetic algorithm for disassembly line balancing[J]. Eur J Oper Res 179:692-708

31. ZHANG Y, HU X (2017) A modified multi-objective genetic algorithm for two-sided assembly line re-balancing problem of a shovel loader[J]. Int J Prod Res 56:3043-3063

32. Su Yajun. Variable neighborhood search algorithm for disassembly line balancing problem[D]. Chengdu:Southwest JIAOTONGUniversity,2015(in Chinese) 
33. Tian Yongting. Parallel disassembly sequence planning method for complex product remanufacturing[D]. Huhhot:Inner Mongol University of Technology,2019(in Chinese)

34. Xuhui XIA, Meng ZHOU, Lei WANG et al Remanu-facturing disassembly service line and balancing optimi-zation method[J].Computer Integrated Manufacturing Systems,2018, 24(10):2492-2501.(in Chinese)

\section{Figures}

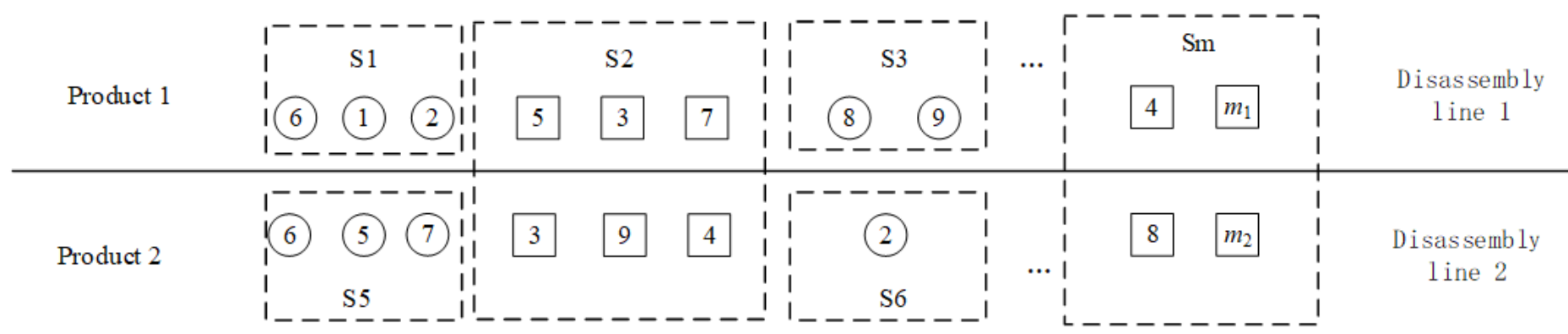

$\square$ - Component disassembl ied in fixed-flow disassembly station

$\bigcirc$ - Component disas semblied in single disassembly station

\section{Figure 1}

Parallel mixed-flow remanufacturing disassembly line layout diagram

Parallel mixed-flow disassembly task allocation matrix

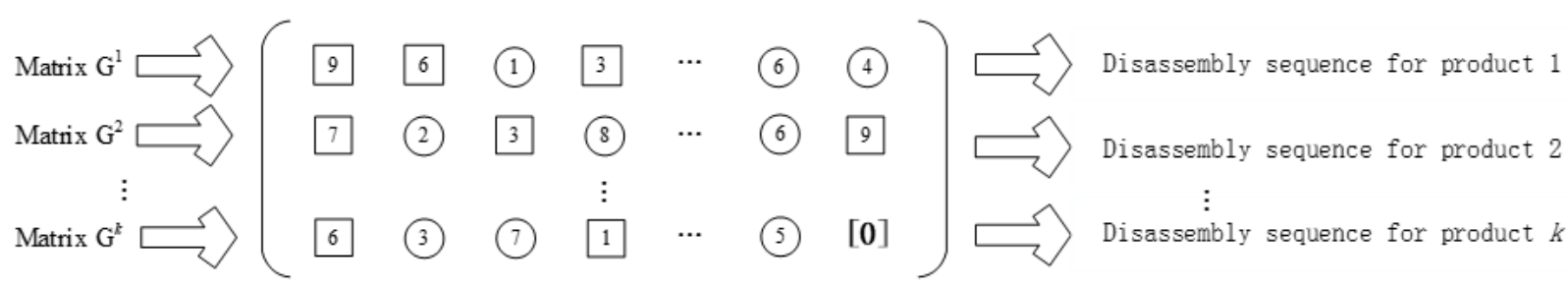

$\square$ - A component that can be mixed disassembled

- A component that is removed independently

\section{Figure 2}

Parallel mixed-flow disassembly task allocation matrix 


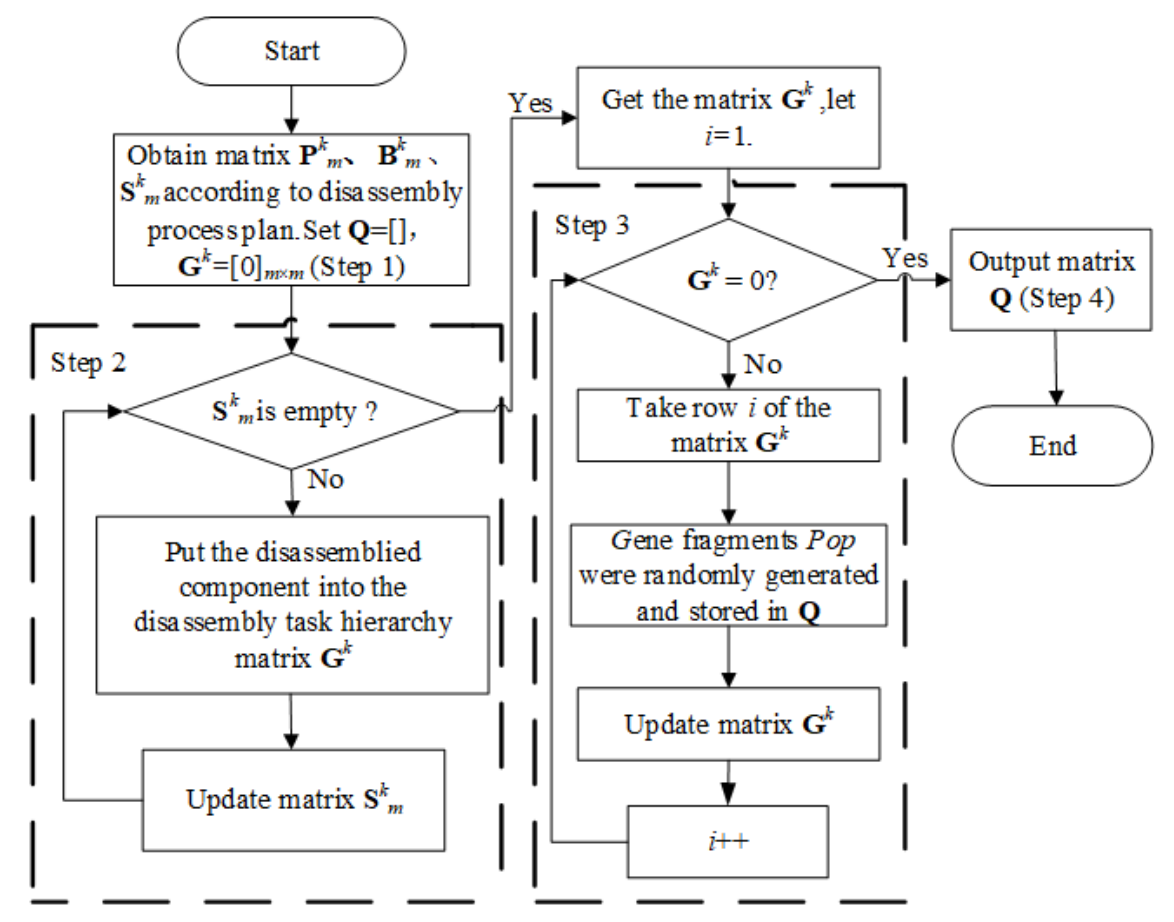

Figure 3

Chromosome acquisition flowchart

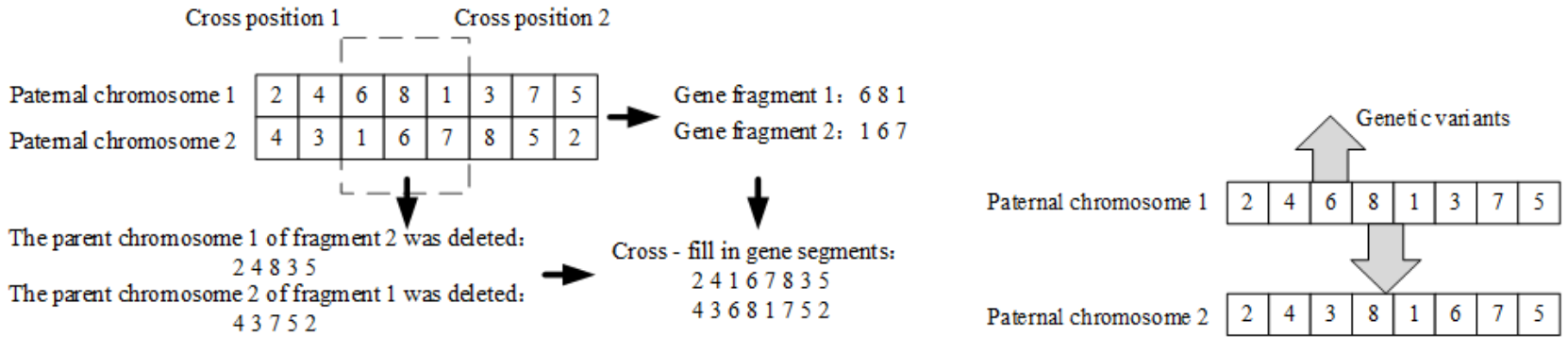

(a) Schematic diagram of crossover evolution

(b) Schematic diagram of variation and evolution

Figure 4

Schematic crossover and variation diagram 


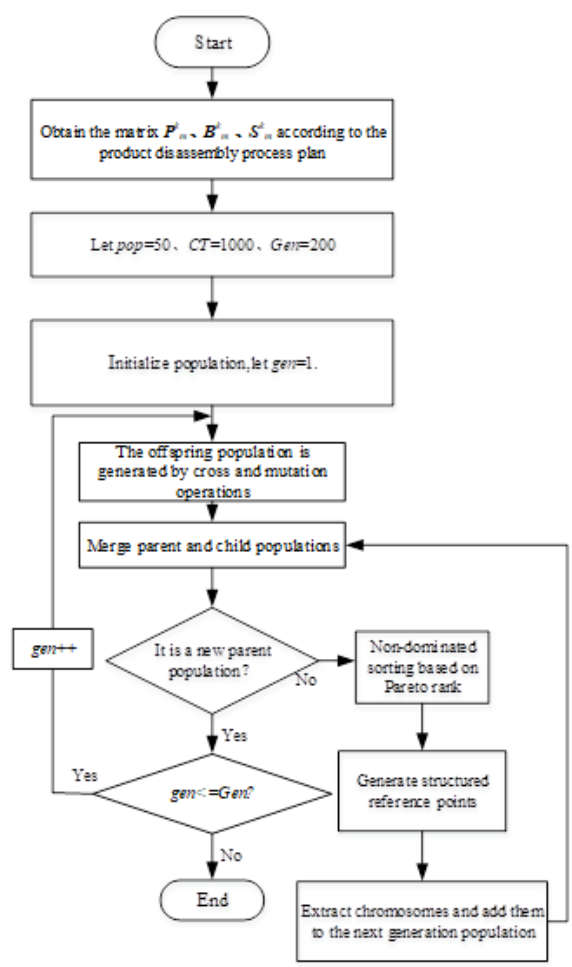

Figure 5

Flowchart for the PMRDLB problem solution process

\begin{tabular}{|c|c|c|c|c|c|c|c|c|}
\hline Disassembly L ine 1 & 11 & 11 & i & 11 & i! & 11 & (15 & i \\
\hline $21,18,8,3,9$ & II $19,22,4,1,5,23$ & $117,2,16,6,7,10$ & $112,11,13,14,15,25,24$ & \begin{tabular}{|l|l|} 
& \\
4 & 20 \\
i The total
\end{tabular} & \begin{tabular}{lll} 
\\
\hdashline
\end{tabular} & $\begin{array}{lll} & 34,30,31,32 \\
\end{array}$ & $\begin{array}{lll}0 & 1 \\
1 & 1 \\
1 & 1 \\
1 & 1 \\
& 1 & 1 \\
\end{array}$ & $\begin{array}{l}1 \\
1 \\
1\end{array}$ \\
\hline $\begin{array}{l}\text { The total time of } \\
\text { workstation } 1 \text { is } 820 \mathrm{~s} \\
\text { and the remaining time } \\
\text { is } 46 \mathrm{~s}\end{array}$ & $\begin{array}{l}\text { II The total time of } \\
\text { II workstation } 2 \text { is } 820 \mathrm{~s} \\
\text { II and the remaining time } \\
\text { II is } 18 \mathrm{~s} \\
\text { II }\end{array}$ & $\begin{array}{l}\text { II The total time of } \\
\text { II workstation } 3 \text { is } 820 \mathrm{~s} \\
\text { II wa } \\
\text { II and the remaining time } \\
\text { II } \text { is } 9 \mathrm{~s} \\
\text { II }\end{array}$ & $\begin{array}{l}\text { The total time of } \\
\text { workstation } 4 \text { is } 820 \mathrm{~s} \text { and } \\
\text { the rem aining time is } 31 \mathrm{~s}\end{array}$ & 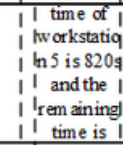 & $\begin{array}{l}\text { I The total time of I } \\
9 \text { workstation } 6 \text { is । } \\
\text { I } 820 \text { s and the I } \\
\text { I rem aining time is } \\
\text { g) } 64 \mathrm{~s}\end{array}$ & $\begin{array}{l}\text { The tota time of } \\
\text { workstation } 7 \text { is } \\
820 \text { s and the } \\
\text { I rem aining time is } \\
24 \mathrm{~s}\end{array}$ & $\begin{array}{l}\text { The total time of workstation } \\
\text { time is } 28 \mathrm{~s}\end{array}$ & $\begin{array}{l}\text { The total time } \\
1, \text { of workstation } \\
9 \text { is } 820 \text { s and } \\
\text { the rem aning }\end{array}$ \\
\hline $1,7,13,17,19$ & II $35,5,12,32,16$ & $\begin{array}{l}\text { II } \\
\text { II } 2,8,10,30,11 \\
\text { II }\end{array}$ & $15,29,6,9,33,18$ & \begin{tabular}{l|l|} 
& $100 \mathrm{~s}$ \\
1 & 14 \\
\end{tabular} & : & 11 & $28,25,24,27,23,22,21$ & $\begin{array}{c}\text { time is } 3 \mathrm{~s} \\
36,26.20\end{array}$ \\
\hline Disassembly L ine 2 & 11 & 11 & I & 11 & 1 & 1 & 1 & \\
\hline
\end{tabular}

\section{Figure 6}

Parallel mixed-flow disassembly line layout for plan 1 